\title{
Adoptive Transfer of Fluorescently Labeled Immune Cells in Xenopus
}

\author{
Kun Hyoe Rhoo ${ }^{1,2}$ and Jacques Robert ${ }^{1}$ \\ ${ }^{1}$ Department of Immunology Microbiology and Virology, University of Rochester, Medical Center, \\ New York 14620
}

Adoptive cell transfer from inbred adult Xenopus to inbred tadpoles is a useful way to study the dissemination of immune cells or pathogen-infected immune cells in tadpoles. For example, Xenopus peritoneal leukocytes (PLs) can be readily infected by pathogens such as Frog virus 3 (FV3) and Mycobacterium marinum (M. marinum). By transferring fluorescently labeled, FV3-infected PLs into tadpoles, we observed infiltration of these cells into the tadpole's brain, which indicates that FV3infected PLs can cross blood brain barrier. Taking advantage of tadpoles' transparency, fluorescently labeled immune cells can be tracked in real time using fluorescence microscopy.

MATERIALS

It is essential that you consult the appropriate Material Safety Data Sheets and your institution's Environmental Health and Safety Office for proper handling of equipment and hazardous materials used in this protocol.

RECIPES: Please see the end of this protocol for recipes indicated by $<R>$. Additional recipes can be found online at http://cshprotocols.cshlp.org/site/recipes.

\section{Reagents}

Amikacin (25 mg/mL) (optional; see Step 2)

Amphibian phosphate-buffered saline (APBS; sterile) $<\mathrm{R}>$

Amphibian serum free (ASF) medium supplemented with fetal bovine serum (FBS) $<\mathrm{R}>$

Cells obtained from Protocol: Flow Cytometry on Xenopus Immune Cells (Edholm 2018)

Cells can be isolated from the animals' blood, peritoneal leukocytes (PLS), lymphoid tissues (spleen, thymus, and bone marrow) or nonlymphoid tissues such as kidney, intestine, or liver. Follow Protocol: Flow Cytometry on Xenopus Immune Cells (Edholm 2018) to isolate cells for transfer. Use MHC homozygous inbred J(j/j) adult frogs or a different inbred strain such as $F(\mathrm{f} / \mathrm{f})$ for the procedure. Cell yield will be different depending on what tissue is used. For example, we can isolate at least $1 \times 10^{6}$ cells from the peritoneal lavage of a single adult animal.

More specific immune cell subsets can be used for transfer (e.g., B or T cells) by further purification or enrichment using either magnetic cell sorting or fluorescence-activated cell sorting (FACS). Prepare cells under sterile conditions.

Red fluorescent membrane dye PKH26 (Sigma-Aldrich) or green fluorescent CFSE tracer (Invitrogen) Tadpoles, J inbred strain, stage 55

\footnotetext{
${ }^{2}$ Correspondence: Kunhyoe_rhoo@urmc.rochester.edu

From the Xenopus collection, edited by Hazel L. Sive.

(c) 2019 Cold Spring Harbor Laboratory Press

Cite this protocol as Cold Spring Harb Protoc; doi:10.1101/pdb.prot097592
} 
K.H. Rhoo and J. Robert

Texas red dextran (Sigma-Aldrich)

Trypan blue solution (Thermo Fisher Scientific)

Trypsin-EDTA (0.25\%; Gibco)

Tween 80 (optional; see Step 2)

Viral (FV3) or bacterial (M. marinum) pathogens (optional; see Step 2)

Equipment

Beckman Coulter Allegra 21R Centrifuge

Conical tubes (15-mL)

Glass capillaries

Hemocytometer

Incubator $\left(27^{\circ} \mathrm{C}\right)$

Inverted fluorescence microscope (Axiovert 200)

Microcentrifuge tubes $(1.5-\mathrm{mL})$

Micropipette puller (Sutter Instrument Co.)

Microscope slides and coverslips

Six-well plate

\section{METHOD}

1. Seed between $3 \times 10^{5}$ to $1 \times 10^{6}$ isolated cells per well in a six-well plate. Incubate cells in each well with $2 \mathrm{~mL}$ of ASF medium with FBS in a standard incubator for $1 \mathrm{~d}$ at $27^{\circ} \mathrm{C}$ to rest the activated cells before infection.

2. If using macrophages infected with pathogens for adoptive transfer, infect these cells with viral (FV3) or bacterial (M. marinum) pathogens of interest with a multiplicity of infection (MOI) between 0.1 and 1 for a desired time in culture.

\section{Infect Cells with FV3}

i. Follow the in vitro infection protocol described in De Jesus Andino et al. (2016).

\section{Infect Cells with M. marinum}

ii. Enrich PLs for macrophages using heat-killed E. coli stimulation (Robert et al. 2014).

iii. Co-incubate PLs with 0.1 MOI M. marinum in APBS containing 0.05\% Tween 80 for $2 \mathrm{~h}$ in culture at $27^{\circ} \mathrm{C}$.

The volume depends on the number of cells that you desire to infect. For example, if you have approximately 1 million cells to infect, you may seed them in one well of six-well plate and use total volume of 3$5 \mathrm{~mL}$. The number of cells also depends on the yield (i.e., how many PLs or liver cells were isolated).

iv. Remove the supernatant, and replace it with ASF medium with FBS containing amikacin $(100 \mu \mathrm{g} / \mathrm{mL})$. Incubate for $2 \mathrm{~h}$ to remove unphagocytosed M. marinum.

Use the same volume of ASF with FBS containing amikacin as you used for M. marinum infection. For example, if M. marinum infection occurs in the six-well plate with total volume will be 3-5 $\mathrm{mL}$, the new medium that replaces it will also be $3-5 \mathrm{~mL}$.

Proceed to Step 3.

3. Remove supernatant. Detach the cells from the six-well plate by adding $1 \mathrm{~mL}$ of $0.25 \%$ trypsin-EDTA to each well. Incubate for $5 \mathrm{~min}$ at $27^{\circ} \mathrm{C}$. Place collected cells in $15-\mathrm{mL}$ conical tubes. (Cells from multiple wells may be pooled.) Centrifuge cells for $10 \mathrm{~min}$ at $400 \mathrm{~g}$ at $4^{\circ} \mathrm{C}$. Remove supernatant.

4. Resuspend cells in $1 \mathrm{~mL}$ of APBS, and transfer the cells to a microcentrifuge tube. Count the cells using a hemocytometer. Pellet the cells as in Step 3. 
5. Fluorescently label the cells with either CFSE or PKH26.

\section{Label the Cells with PKH26 (Red Fluorescence)}

i. Resuspend up to $2 \times 107$ cells in each $1 \mathrm{~mL}$ of Diluent $\mathrm{C}$ (a component of the PKH labeling kit). Then mix cells with an equal volume of $4 \mu \mathrm{M}$ PKH26. Incubate the mixture for $15 \mathrm{~min}$ at $27^{\circ} \mathrm{C}$.

The final cell concentration will be $1 \times 10^{7} \mathrm{~mL}$, and the final concentration of PKH26 will be $2 \mu \mathrm{M}$.

ii. Stop the reaction by adding $2 \mathrm{~mL}$ of ASF with FBS.

iii. Pellet the cells by centrifugation at $9000 \mathrm{~g}$ for $30 \mathrm{sec}$ at room temperature. Decant the supernatant, and wash with $1 \mathrm{~mL}$ of APBS.

iv. Repeat Step 5.iii two more times.

$\mathrm{v}$. Resuspend the pellet in $1 \mathrm{~mL}$ of APBS. To determine if the cells are properly labeled with red fluorescence, place an aliquot of cells on a glass microscope slide and look for red signal under the fluorescence microscope.

\section{Label the Cells with CFSE (Green Fluorescence)}

vi. Resuspend up to $2.5 \times 10^{6}$ cells in $50 \mu \mathrm{L}$ of $40 \mu \mathrm{M}$ CFSE (diluted in DMSO; included in supplier package) in a microcentrifuge tube. Incubate for $15 \mathrm{~min}$ at $27^{\circ} \mathrm{C}$.

vii. Quench CFSE by adding $250 \mu \mathrm{L}$ of ASF with FBS, and incubate for 7 min at $27^{\circ} \mathrm{C}$. Flick with fingers every $2 \mathrm{~min}$.

viii. Add $1 \mathrm{~mL}$ of APBS and pellet the cells by centrifugation at $9000 \mathrm{~g}$ for $30 \mathrm{sec}$ at room temperature. Decant the supernatant.

ix. Repeat Step 5.viii two more times.

$\mathrm{x}$. Resuspend the pellet in $1 \mathrm{~mL}$ of APBS. To determine if the cells are properly labeled with green fluorescence, place an aliquot of cells on a glass microscope slide and look for green signal under the fluorescence microscope.

6. Count a sample of the cells using a hemocytometer and determine cell death by Trypan blue exclusion test. Note the percent of cell death as you proceed further.

7. Inject 100,000 labeled cells intraperitoneally into J inbred tadpoles of stage 55 ( 3 to 4 wk of age) as follows.

i. Centrifuge the fluorescently labeled cells at $9000 \mathrm{~g}$ for $30 \mathrm{sec}$ at room temperature, and resuspend the cells in $10 \mu \mathrm{L}$ of sterile APBS.

ii. Use a micropipette puller to generate microinjecting needles from standard glass capillaries (see Protocol: Elicitation of Xenopus laevis Tadpole and Adult Frog Peritoneal Leukocytes [Grayfer 2018]).

iii. Load the cells in the back opening of the glass capillary using a thin micropipette tip. Inject the cells directly into the tadpole's peritoneum using the microinjection technique described in Protocol: Elicitation of Xenopus laevis Tadpole and Adult Frog Peritoneal Leukocytes [Grayfer 2018].

Alternatively, the labeled cells can be injected into the blood circulation through the aorta using the same microinjection technique above.

8. Visualize adoptively transferred cells using intravital fluorescence microscopy in the whole tadpoles or the harvested organs.

The cells can be visualized within a few hours to a day. See Troubleshooting.

Alternatively, cells can be isolated from organs or recovered from the peritoneal fluid for flow cytometry analysis (see Protocol: Flow Cytometry on Xenopus Immune Cells [Edholm 2018]; Paredes et al. 2015). 
Problem (Step 8): Poor fluorescence signal of the labeled cells is observed.

Solution: When CFSE is purchased, it comes in several aliquots. Because CFSE is sensitive to humidity, reusing aliquots is not recommended. Check the fluorescence before the adoptive transfer to make sure that the fluorescence can be detected in culture.

Problem (Step 8): Adoptively transferred cells not found.

Solution: Ensure that the donor and recipient are both inbred J strains by skin grafting or MHC class Ia gene typing (Flajnik and Du Pasquier 1990). Since some cells are fragile and die rapidly, it is a good idea to save some cells in culture as a backup and measure cell death after a few days. If necessary, it is also possible to transfer more cells (e.g., $1 \times 10^{6}$ cells).

\section{DISCUSSION}

This technique can be used to study homing or infiltration of adoptively transferred cells into particular organs or tissues. For example, we used this adoptive cell transfer system to study the ability of FV3-infected PLs to cross the blood brain barrier. We have successfully visualized the donor's peritoneal macrophages infected with FV3 infiltrating into the recipient tadpole's brain at stage 55 when the BBB is fully functional (De Jesus Andino et al. 2016). In another example, adoptive cell transfer in Xenopus has been used to study the immunization role of heat shock proteins (hsp). When PLs pulsed with gp96 chaperoning minor H-Ag were adoptively transferred from minor H-Agmismatched donors to recipients, the transferred cells were successfully detected in the recipient's spleen and the appearance of tumors were delayed in these immunized recipients (Maniero and Robert 2004).

Using confocal microscopy instead of conventional fluorescence microscopy is an attractive approach to trace fluorescently labeled cells in real time. Confocal microscopy can locate the adoptive transferred cells in three-dimensional structure with high resolution. Recently, we successfully used confocal microscopy to study the dynamic structure of cell aggregation (e.g., granulomas) following M. marinum infection. In parallel, it is also possible to label blood vessels by injecting Texas Red Dextran into the heart $(25 \mathrm{mg} / \mathrm{mL} ; 10 \mu \mathrm{L}$ of volume) to provide a better localization of infiltrated cells.

Amphibian Phosphate-Buffered Saline (APBS)

Sodium chloride $(\mathrm{NaCl})$

Sodium phosphate $\left(\mathrm{Na}_{2} \mathrm{HPO}_{2}\right)$

Potassium phosphate $\left(\mathrm{KH}_{2} \mathrm{PO}_{4}\right)$
$6.6 \mathrm{~g} / \mathrm{L}$

$1.15 \mathrm{~g} / \mathrm{L}$

$0.2 \mathrm{~g} / \mathrm{L}$

Adjust $\mathrm{pH}$ to 7.7 with $10 \mathrm{~N} \mathrm{NaOH}$, and filter-sterilize through a $0.2-\mu \mathrm{m}$ filter. Store at room temperature for up to $6 \mathrm{mo}$. 
Amphibian Serum-Free (ASF) Medium Supplemented with Fetal Bovine Serum (FBS)

\begin{tabular}{ll} 
Reagent & Quantity \\
\hline Iscove's DMEM basal medium, powdered (Gibco 12200-036) & 1 package \\
Insulin (Sigma-Aldrich 19278-5mL) & $10 \mathrm{~mL}$ \\
Nonessential amino acids (Gibco 11140-050) & $10 \mathrm{~mL}$ \\
Penicillin-streptomycin (Gibco 15070-063) & $10 \mathrm{~mL}$ \\
Primatone (Sheffield Products Division) & $3 \mathrm{~mL}$ \\
2-mercaptoethanol & $1 \mathrm{~mL}$ \\
$\mathrm{NaHCO}_{3}$ & $3.02 \mathrm{~g}$
\end{tabular}

Combine the above ingredients in water. Adjust the $\mathrm{pH}$ to 7.0 with $10 \mathrm{~N} \mathrm{NaOH}$, and bring the final volume to $1 \mathrm{~L}$. Filter through a $0.2-\mu \mathrm{m}$ filter, and store at $4^{\circ} \mathrm{C}$. On the day of use, prepare the desired volume of ASF by adding 30\% double-distilled water, $10 \%$ fetal bovine serum (FBS), and $10 \mu \mathrm{g} / \mathrm{mL}$ kanamycin to the appropriate volume of solution.

This recipe was adapted from Robert et al. (2004).

\section{REFERENCES}

De Jesus Andino F, Jones L, Maggirwar SB, Robert J. 2016. Frog Virus 3 dissemination in the brain of tadpoles, but not in adult Xenopus, involves blood brain barrier dysfunction. Sci Rep 6: 22508.

Edholm ES. 2018. Flow cytometry on Xenopus immune cells. Cold Spring Harb Protoc doi: 10.1101/pdb.prot097600.

Flajnik MF, Du Pasquier L. 1990. The major histocompatibility complex of frogs. Immunol Rev 113: 47-63.

Grayfer L. 2018. Elicitation of Xenopus laevis tadpole and adult frog peritoneal leukocytes. Cold Spring Harb Protoc doi: 10.1101/pdb.prot097642.

Maniero GD, Robert J. 2004. Phylogenetic conservation of gp96-mediated antigen-specific cellular immunity: New evidence from adoptive cell transfer in Xenopus. Transplantation 78: 1415-1421.
Paredes R, Ishibashi S, Borrill R, Robert J, Amaya E. 2015. Xenopus: An in vivo model for imaging the inflammatory response following injury and bacterial infection. Dev Biol 408: 213-228.

Robert J, Gantress J, Cohen N, Maniero GD. 2004. Xenopus as an experimental model for studying evolution of hsp-immune system interactions. Methods 32: 42-53.

Robert J, Grayfer L, Edholm ES, Ward B, De Jesus Andino F. 2014. Inflammation-induced reactivation of the ranavirus Frog Virus 3 in asymptomatic Xenopus laevis. PLoS One 9: e112904. 


\section{Adoptive Transfer of Fluorescently Labeled Immune Cells in Xenopus}

Kun Hyoe Rhoo and Jacques Robert

Cold Spring Harb Protoc; doi: 10.1101/pdb.prot097592 originally published online July 6, 2018

\begin{tabular}{|c|c|}
\hline $\begin{array}{r}\text { Email Alerting } \\
\text { Service }\end{array}$ & Receive free email alerts when new articles cite this article - click here. \\
\hline $\begin{array}{l}\text { Subject } \\
\text { Categories }\end{array}$ & $\begin{array}{l}\text { Browse articles on similar topics from Cold Spring Harbor Protocols. } \\
\text { Cell Biology, general (1382 articles) } \\
\text { Cell Imaging (525 articles) } \\
\text { Fluorescence ( } 517 \text { articles) } \\
\text { Fluorescence, general (341 articles) } \\
\text { Immunology, general (128 articles) } \\
\text { In Vivo Imaging ( } 334 \text { articles) } \\
\text { Live Cell Imaging (274 articles) } \\
\text { Xenopus ( } 210 \text { articles) }\end{array}$ \\
\hline
\end{tabular}

